\title{
Analisis Kestabilan dan Keuntungan Maksimum Model Predator-Prey Fungsi Respon Tipe Holling III dengan Usaha Pemanenan.
}

\author{
Didiharyono \\ Universitas Andi Djemma Palopo \\ Email:muh.didih@gmail.com
}

\begin{abstract}
In this paper, we discussed stability analysis of predator-prey model with Holling type III and will harvesting effort at second populations. The research aimed is, to investigate solution the predator-prey model with Holling type III functional response with addition harvesting effort and to investigate maximum profit from optimal harvesting at second populations. Stability of equilibrium point use linearization method and determine the stability by notice the eigenvalues of Jacoby matrix evaluation of equilibrium point and can also be determined using Hurwitz stability test by observing the coefficients of the characteristic equation. The result shows that the obtained an interior point $\operatorname{TE}_{2}^{*}\left(x^{*}, y^{*}\right)$ which asymptotic stable according to Hurwitz stability test and find maximum profit of exploitation effort or harvest at second populations. Predator-prey population is always exist in their life, although exploitation with harvesting effort and given maximum profit is $\pi_{\max }=$ 162.68 where to find maximum profit on critical points of surface profit function.
\end{abstract}

Key word: Predator prey model, harvesting, equilibrium point, stability and maxsimum profit.

\section{PENDAHULUAN}

Perkembangan pemodelan matematika terus mendukung perkembangan beberapa ilmu terapan lainnya, terutama dalam penggunaan metodologi penelitiannya yang bisa menggunakan berbagai rumusan matematika. Pemodelan matematika bukan hanya ditemukan pada bidang matematika dan statistika saja, namun pemodelan matematika hampir dapat dijumpai pada seluruh cabang ilmu pengetahuan baik kedokteran, biologi, ekologi, ekonomi dan lain sebagainya. Model matematika ini berkontribusi dalam memudahkan fenomena alam yang abstrak untuk disimulasikan dalam bentuk rumusan matematika.

Langkah pertama dari proses yang kompleks ini berupa pengamatan mengenai system real yang dimodelkan. Pengamatan juga berarti pengorganisasian dari asumsi-asumsi model yang kemudian akan menyedian informasi kuantitatif dari model matematika. Kemudian model matematika digeneralisasikan dan diformalisasikan dengan metode khusus sebagaimana yang ada dalam metodologi penelitian matematika. Secara umum pemodelan matematika merupakan usaha perancangan rumusan atau metode matematika menggambarkan peneyelesaian masalah matematika yang digeneralisasikan untuk diterapkan pada perilaku dan fenomena alam.

Model matematika digunakan untuk menjelaskan fenomena alam yang terjadi, serta dapat digunakan untuk memprediksi perilaku sistem untuk jangka waktu tertentu. Pemodelan matematika pada bidang ekologi dan economi sangat menarik untuk dikaji mengingat banyak sekali faktor-faktor yang mempengaruhi kehidupan populasi mahluk hidup dan keseimbangan mahluk hidup serta interaksi mereka dalam kehidupan. Proses dinamika 
kehidupan makhluk hidup (organisme) dapat dimodelkan secara matematis dengan menggunakan persamaan differensial yang melibatkan waktu yang kontinu atau waktu yang diskrit (Agarwal, 2012).

Salah satu model matematika yang digunakan dalam menjelaskan fenomena tersebut adalah model populasi mangsa-pemangsa. Hubungan antara spesies pemangsa dan spesies yang dimangsanya sangatlah erat, pemangsa tidak akan dapat hidup jika tidak ada mangsa. Selain itu, pemangsa juga berperan sebagai pengontrol populasi mangsa. Menurut Toaha (2013) bahwa Interaksi antar spesies yang terjadi dalam suatu ekosistem dapat menyebabkan keadaan populasi suatu spesies berubah. Interaksi tersebut dapat memberikan dampak positif, negatif atau bahkan tidak berpengaruh terhadap spesies-spesies yang berinteraksi. Salah satu penyebab kepunahan populasi adalah tingkat pemangsaan terhadap populasi mangsa yang sangat tinggi dan rendahnya tingkat pertumbuhan mangsa atau rendahnya populasi awal dari populasi mangsa.

Banyak peneliti yang mengembangkan model Lotka-Volterra (predator-prey) dengan menambahkan beberapa asumsi. Srinivasu dkk., (2001) mengkaji model Lotka-Voltera dengan mengontrol system pemamenan dari model tersebut dan Kar (2003) mengkaji model Lotka-Voltera dengan menambahkan pengaruh waktu tunda pada pemanenan yang selektif. Kemudian Zhang dkk., (2011) mengkaji model Lotka Voltera dengan fungsi respon tipe Holling III pada interaksi antara mangsa-pemangsa dengan usaha pemanenan konstan pada populasi mangsa.

Agarwal dkk., (2012) dan Jiang (2013) mengembangkan model tersebut dengan menambahkan usaha pemanenan konstan pada populasi mangsa pemangsa. Model tersebut tetap dikembangan juga oleh Liu dkk., (2012) dan Wang dkk., (2012) yang konsen mengkaji usaha pemanenan populasi mangsa dengan menyertakan mangsa pelarian (refuge). Selanjutnya, pada penelitian Zhao dkk., (2013) melihat efek atau pengaruh mangsa pelarian (refuge) terhadap keadaan awal populasi mangsa.

Oleh karena itu, dalam tulisan ini penulis menganalisis model Lotka-Voltera dengan fungsi respon tipe Holling III pada populasi mangsa-pemangsa (predator-prey) dengan asumsinya bahwa kedua populasi tersebut merupakan populasi yang sangat bermanfaat bagi kehidupan manusia, sehingga terjadi usaha pemanenan. Penelitian ini betujuan, untuk mengetahui solusi model mangsa-pemangsa yang mengikuti tipe Holling III dengan menambahkan usaha pemanenan pada populasi mangsa-pemangsa dan untuk mengetahui keuntungan maksimum dari usaha pemanenan yang optimal pada kedua populasi tersebut.

\section{TINJAUAN PUSTAKA}

\section{A. Model Dasar Mangsa Pemangsa}

Model Lotka-Voltera menyatakan bahwa hubungan fungsional antara perubahan ukuran populasi mangsa dan pemangsa pada saat sekarang bergantung pada ukuran populasi mangsa $x(t)$ dan ukuran populasi mangsa $y(t)$, pada saat sekarang diberikan sebagai:

$$
\begin{aligned}
& \frac{d x}{d t}=r x-\alpha x y \\
& \frac{d y}{d t}=-c y+\beta x y
\end{aligned}
$$


Model populasi mangsa pemangsa tersebut menyatakan laju pertumbuhan mangsa $x(t)$ pada saat $t$ bertambah secara proporsional dengan ukuran popuasi mangsa dan laju pertumbuhannya berkurang dengan adanya interaksi antara populasi mangsa dan populasi pemangsa yang dinyakatan oleh $\alpha x(t) y(t)$. Sementara itu, laju pertumbuhan populasi pemangsa $y(t)$ pada saat $t$ berkurang secara proporsional dengan ukuran populasi pemangsa dan laju pertumbuhannya bertambah dengan adanya interaksi antara populasi mangsa dan populasi pemangsa yang dinyatkan oleh $\beta x(t) y(t)$.

Selanjutnya, dengan mempertimbangkan kepadatan populasi atau pengaruh daya dukung lingkungan maksimal $K$, maka dengan itu model (2.1) dikembangkan menjadi:

$$
\begin{aligned}
& \frac{d x}{d t}=r x\left(1-\frac{x}{K}\right)-\alpha x y \\
& \frac{d y}{d t}=-c y+\beta x y
\end{aligned}
$$

Model (2.2) melibatkan parameter $K$, yang menyatakan jumlah maksimal populasi mangsa yang dapat ditampung oleh lingkungannya ketika populasi pemangsa tidak ada. Paramater $r$ menyatakan laju pertumbuhan intrinsik populasi mangsa, $c$ adalah laju kematian populasi pemangsa, $\alpha$ mengukur laju konsumsi mangsa oleh pemangsa, $\beta$ mengukur konversi mangsa yang dikonsumsi pemangsa ke dalam laju reproduksi pemangsa. Semua parameter persamaan model (2.2) diasumsikan bernilai positif. (Toaha, 2013).

\section{B. Model Logistik}

Populasi mangsa tidak selamanya meningkat atau populasi pemangsa tidak semalanya menurun, tetapi dapat terjadi jika populasi naik maka angka pertumbuhan cenderung turun. Bahkan untuk populasi yang cukup besar, bukan mustahil angka pertumbuhan negatif. Fenomena ini disebabkan area dan fasilitas hidup terbatas atau daya dukung lingkungan atau Kapasitas Batas (Carrying Capasity).

Laju pertumbuhan populasi tidak tetap tertapi bergantung pada ukuran populasi. Jika hal ini dijadikan asumsi, secara matematis berarti bahwa laju pertumbuhan populasi tersebut merupakan fungsi ukuran populasi,

$$
\frac{d x}{d t}=f(x)
$$

Dengan $f(x)$ merupakan fungsi turun jika $x$ bertambah besar. Nilai $f(x)$ akan bertambah besar jika $x$ mendekati nol. Sedangkan, bentuk sederhana dari fungsi $f$ ialah bentuk linear yaitu, jika $x$ sangat kecil $(x \rightarrow 0)$, populasi tumbuh secara eksponensial dan setiap individu yang ditambah ke dalam populasi akan mengakibatkan laju pertumbuhan perkapita turun sebesar konstanta $a$, maka persamaan differensial untuk pertumbuhan populasi akan menjadi:

$$
\frac{1}{x} \frac{d x}{d t}=r-b x
$$
berikut:

Kemudian, memisalkan $b=r / K$ maka model (2.4) dinyatakan dalam bentuk

$$
\frac{d x}{d t}=r x\left(1-\frac{x}{K}\right)
$$


Dengan $r$ dan $b$ merupakan konstanta positif, yang merupakan laju pertumbuhan intrinsik karena nilai laju pertumbuhan mendekati nilai $r$ ketika ukuran populasi $x$ kecil. Konstanta positif daya dukung (carrying capacity) $K$ merupakan ukuran populasi maksimal yang dapat ditampung dengan baik oleh lingkungan dimana populasi tersebut hidup. Persamaan (2.5) inilah yang disebut dengan model logistik. (Brauer, 2012).

\section{Model Holling}

Ada banyak model mangsa pemangsa yang ditemui dalam bidang ekologi, salah satunya adalah model Holling. Sebagaimana telah disebutkan dalam Toaha (2013) bahwa suatu model mangsa pemangsa dengan tipe Holling yang menggunakan usaha pemanenan sebagai suatu kontrol yang telah dipresentaiskan oleh Srinivasu, dkk (2001), dimana hasil yang diperoleh menunjukan bahwa usaha pemanenan dapat menyebabkan perilaku siklik dari sistem dan kemungkinan terjadi limit cycle yang stabil.

Pada model Holling tipe II, saat kepadatan populasi mangsa rendah, model tersebut mengambarkan tingkat pemangsaan dari populasi mangsa, sampai pada kepadatan mangsa yang tinggi di mana tingkat konsumsi mencapai titik jenuh. Hal ini disebabkan setiap pemangsa hanya dapat memakan sejumlah kecil mangsa pada saat satu unit waktu. Sedangkan, model tipe Holling III juga menggambarkan tingkat pertumbuhan pemangsa. Tetapi, pada model ini dapat terlihat jelas mengenai penurunan tingkat pemangsaan pada saat kepadatan mangsa rendah.

Adapun tingkat pertumbuhan mangsa pada model tipe Holling II dan tipe Holling III sebagaimana dalam Eisenberg dan Maszle (1995) diberikan pada fungsi berikut:

$$
\begin{aligned}
& F^{\prime \prime}(x)=\frac{g x}{1+h x} \\
& F^{\prime \prime \prime}(x)=\frac{g x^{2}}{1+h x^{2}}
\end{aligned}
$$

Pada model persamaan (2.6), $F^{\prime \prime}(x)$ fungsi tipe Holling II, $F^{\prime \prime \prime}(x)$ fungsi tipe holling III, $x$ jumlah populasi mangsa, konstanta $g$ merupakan tingkat ukuran maksimum populasi mangsa dan konstanta $h$ merupakan ukuran populasi mangsa yang dimangsa oleh pemangsa. Tipe fungsi respon tersebut sangat dipengaruhi oleh jumlah populasi mangsa, atau dengan kata lain semakin banyak populasi mangsa maka semakin banyak persediaan makanan untuk pemangsa.

\section{Titik Ekuilibrium}

Dalam kajian ekologi istilah keseimbangan (ekuilibrium) sangat umum dipakai untuk menggambarkan keadaan dinamika sistem yang tidak mengalami gejolak. Apabila suatu sistem yang berada dalam keadaan seimbang salah satu sub sistem atau komponen sistemnya mengalami gangguan (perturbasi) maka seluruh sistem akan berubah. Besarnya perubahan mungkin dalam kuantitas yang sangat kecil, tetapi setelah beberapa waktu perturbasi ini dapat memberikan akibat yang mungkin tidak terduga sebelumnya. Perturbasi yang kecil dapat juga menyebabkan peningkatan populasi untuk beberapa waktu jika terjadi peningkatan dalam pertumbuhan populasi (jumlah kelahiran lebih besar dari jumlah kematian). Perubahan dalam keseimbangan pertumbuhan populasi yang berbentuk suatu gejolak yang besar dapat menyebabkan kerusakan terhadap ekosistem, kepunahan populasi atau ledakan yang membawa bencana. 
Keadaan seimbang yang stabil dalam literatur ekologi disebut stable equilibrium atau steady state. Dalam keadaan demikian perubahan-perubahan yang berlangsung dalam sistem dianggap sangat kecil dan tidak terlihat gejolak-gejolak yang berarti. Salah satu contoh adalah hutan alam yang dalam keadaan klimaks, atau hutan-hutan sekunder yang telah melalui beberapa suksesi dan mencapai keadaan seimbang yang stabil. (Tarumingkeng, 1994). Untuk lebih jelasnya, dimisalkan suatu sistem persamaan differensial dinyatakan sebagai berikut:

$$
\frac{d x}{d t}=f(x)
$$

Titik ekuilibrium merupakan titik gerak vektor keadaan konstan. Atau bisa juga dikatakan bahwa titik ekuilibrium merupakan solusi yang tetap konstan meskipun waktu berganti. Titik ekuilibrium persamaan (2.7) didapatkan jika $\frac{d x}{d t}=0$. Titik ekuilibrium atau titik keseimbangan biasa juga disebut sebagai titik tetap, titik stationer, rest point (titik sentral), singularity, critical point atau ekuilibrium state (keadaan seimbang). Menurut Toaha (2013) solusi yang demikian disebut solusi setimbang (ekuilibrium solution) atau trajektori konstan (constant trajectory) dan jika $x=0$, maka solusi tersebut dikatakan solusi nol.

\section{E. Nilai Eigen Dan Vektor Eigen}

Misalkan A adalah matriks $n \times n$. Sebuah vektor tak nol $\mathbf{x}$ di dalam $R^{2}$ disebut vektor eigen dari A, jika untuk sebuah skalar $\lambda$, yang disebut nilai eigen dari $\mathbf{A}$, maka berlaku:

$$
\mathbf{A x}=\lambda \mathbf{x}
$$

Vektor $\mathbf{x}$ disebut vektor eigen yang bersesuaian dengan nilai eigen $\lambda$.

Untuk mencari nilai eigen matriks A yang berukuran $n \times n$, maka persamaan (2.8) dapat dituliskan sebagai berikut:

$$
(\mathbf{A}-\lambda \mathbf{I}) \mathbf{x}=0
$$

dengan I merupakan matriks identitas. Persamaan (2.9) mempunyai solusi tak nol yang jika hanya jika, $\operatorname{det}(\mathbf{A}-\lambda \mathbf{I})=0$ disebut persamaan kateristik dari A. (Anton, 1995)

\section{F. Pelinearan}

Analisis kestabilan sistem persamaan differensial non linear dilakukan melalui pelinearan. Misalkan sistem persamaan differensial non linear sebagai berikut:

$$
\frac{d x}{d t}=f(x)
$$

Dengan menggunakan ekspansi Taylor untuk suatu titik kesetimbangan $\frac{d x}{d t}$. Maka persamaan (2.10) dapat ditulis:

$$
\frac{d x}{d t}=\mathbf{A x}+\varphi(x)
$$

Persamaan tersebut merupakan sistem persamaan differensial non linear dengan $\mathbf{A}$ adalah matrik Jacobi. Untuk mencari hasil pelinearan dari sistem persamaan diferensial non linear digunakan matriks Jacobi. 


$$
A=\left(\begin{array}{cccc}
\frac{\partial f_{1}}{\partial x_{1}} & \frac{\partial f_{1}}{\partial x_{2}} & \cdots & \frac{\partial f_{1}}{\partial x_{n}} \\
\frac{\partial f_{2}}{\partial x_{2}} & \frac{\partial f_{2}}{\partial x_{2}} & \cdots & \frac{\partial f_{2}}{\partial x_{n}} \\
\vdots & \vdots & \ddots & \vdots \\
\frac{\partial f_{m}}{\partial x_{1}} & \frac{\partial f_{m}}{\partial x_{2}} & \cdots & \frac{\partial f_{m}}{\partial x_{n}}
\end{array}\right)
$$

A merupakan matriks Jacobi yang berukuran $m x n$. Matriks ini sering juga ditulis sebagai matriks $\left[\frac{\partial f_{i}}{\partial x_{i}}\right]_{i j}$. Dan $\varphi(x)$ suku berorde tinggi yang bersifat $\lim _{x \rightarrow 0} \varphi(x)=0$. Akibatnya persamaan (2.15) diberikan:

$$
\frac{d x}{d t}=\mathbf{A x}
$$

Persamaan differensial (2.12) merupakan hasil pelinearan dari persamaan differensial (2.11). (Tu, 1994).

\section{G. Analisis Kestabilan}

Misalkan $x_{e}$ adalah suatu titik keseimbangan dari sistem dinamik berikut,

$$
\frac{d x(t)}{d t}=f(x(t), t)
$$

dengan $f\left(x_{e}, t\right)=0$ untuk setiap $t$.

Definisi 2.1. Titik keseimbangan $x_{e}$ atau solusi keseimbangan $x(t)=x_{e}$ dikatakan stabil jika diberikan sebarang $t_{0}$ dan bilangan positif $\varepsilon$, terdapat bilangan positif $\delta\left(\varepsilon, t_{0}\right)$ sedemikian sehingga, jika $\left\|x_{0}-x_{e}\right\|<\delta$ berlaku $\left\|x\left(t ; x_{0}, t_{0}\right)-x_{e}\right\|<\varepsilon$ untuk setiap $t \geq t_{0}$.

Definisi 2.2. Titik keseimbangan $x_{e}$ disebut stabil asimptotik global, jika ia stabil dan setiap trajektori konvergen ke titik keseimbangan tersebut untuk $t$ menuju ke takberhinga. (Toaha, 2013)

Sebagai penjelasannya, pertimbangkan sistem persamaan differensial autonomous dua dimensi berikut:

$$
\begin{aligned}
& \frac{d x}{d t}=a x+b y \\
& \frac{d y}{d t}=c x+d y
\end{aligned}
$$

Dengan asumsi bahwa $a d-b c \neq 0$. Dengan asumsi tersebut maka titik $(0,0)$ merupakan satu-satunya titik keseimbangan untuk sistem (2.13) dengan akar dari persamaan karateristik adalah:

$$
\lambda-(a+d) \lambda+a d-b c=0
$$

Maka sifat stabilitas titik kesetimbangan $(0,0)$ dari persamaan (2.13) hampir seluruhnya tergantung pada akar-akar persamaan (2.14). dengan kata lain kestabilan suatu titik kesetimbangan dapat diperiksa dari nilai eigen sistem tersebut. Persamaan (2.13) 
disebut persamaan differensial mandiri (autonomous) karena tidak memuat $t$ secara eksplisit didalamnya

Teorema 2.1. (Boyce dan Di Prima, 1992). Misalkan $r_{1}$ dan $r_{2}$ adalah nilai eigen dari sistem linear yang bersesuaian dengan sistem non linear. Maka tipe dan kestabilan titik kesetimbangan $(0,0)$ dari sistem linear dan titik kesetimbanga $(x, y)$ dari sistem linear diberikan pada Tabel 2.1 berikut:

Tabel 1 Sifat-sifat kestabilan pada sistem linear dan non liear

\begin{tabular}{|c|c|c|c|c|}
\hline \multirow{2}{*}{$\begin{array}{l}\text { Nilai Eigen } \\
r_{1} \text { dan } r_{2}\end{array}$} & \multicolumn{2}{|r|}{ Sistem Linear } & \multicolumn{2}{|c|}{ Sistem Non Linear } \\
\hline & Tipe & Kestabilan & Tipe & Kestabilan \\
\hline$r_{1}>r_{2}>0$ & IN & Tidak stabil & IN & Tidak stabil \\
\hline$r_{1}<r_{2}<0$ & IN & Stabil Asimptotik & IN & Stabil Asimptotik \\
\hline$r_{2}<0<r_{1}$ & SP & Tidak stabil & SP & Tidak stabil \\
\hline$r_{1}=r_{2}>0$ & PN, IN & Tidak stabil & PN, IN, SpP & Tidak stabil \\
\hline$r_{1}=r_{2}<0$ & PN, IN & Stabil Asimptotik & $\mathrm{PN}, \mathrm{SpP}$ & Stabil Asimptotik \\
\hline \multicolumn{5}{|c|}{$r_{1}, r_{2}=\rho \pm i \omega$} \\
\hline$\rho>0$ & $\mathrm{SpP}$ & Tidak stabil & $\mathrm{SpP}$ & Tidak stabil \\
\hline$\rho<0$ & $\mathrm{SpP}$ & Stabil Asimptotik & $\mathrm{SpP}$ & Stabil Asimptotik \\
\hline$\rho=0$ & $\mathrm{C}$ & Stabil & $\mathrm{C}, \mathrm{SpP}$ & Tak tentu \\
\hline \multicolumn{5}{|c|}{$\begin{array}{l}\text { Catatan: IN: Node tidak sejati, PN: Node sejati, SP: titik pelana, SpP: Spiral, C: } \\
\text { Pusat }\end{array}$} \\
\hline
\end{tabular}

Secara esensial, Teorema 2.1 menyatakan bahwa untuk gangguan yang kecil, nilai bentuk non linear juga kecil dan tidak mempengaruhi kestabilan dan tipe dari titik keseimbangan sebagaimana ditentukan oleh bentuk linear kecuali dalam dua kasus yaitu pertama, $r_{1}$ dan $r_{2}$ adalah bilangan kompleks murni, kedua $r_{1}$ dan $r_{2}$ adalah bilangan real dan bernilai sama. Analisis kestabilan lokal untuk titik keseimbangan $(x, y)$ dari sistem persamaan non linear equivalen dengan analisis kestabilan titik keseimbangan $(0,0)$ yang terisolasi untuk sistem linear (Toaha, 2013).

\section{H. Kriteria Kestabilan Routh-Hurwitz}

Kriteria kestabilan Routh-Hurwitz digunakan apabila nilai eigen dari persamaan karakteristik sistem sulit ditentukan. Karena kriteria kestabilan Routh-Hurwitz ini tidak melihat tanda bagian real dari nilai eigen atau akar-akar persamaan karakteristik secara langsung melainkan melihat koefisien dari persamaan karakteristik. Suatu metode dipertimbangkan untuk menguji kestabilan titik keseimbangan dari sistem dinamik linear dengan koefisien konstan,

$$
\frac{d x}{d t}=\mathbf{A x}
$$

dengan $\mathbf{x}$ adalah matrik yang berukuran $n \times 1$ dan $\mathbf{A}$ adalah matriks yang berukuran $n \times n$.

Teorema 2.2. Diberikan suatu polinomial, 


$$
f(r)=r^{n}+p_{n-1} r^{n-1}+\cdots+p_{2} r^{2}+p_{1} r+p_{0}
$$

dengan $p_{0}, p_{1}, p_{2}, \cdots p_{n-1}$ adalah konstanta real yang mempunyai $n$ akar $r_{1}, r_{2}, \cdots r_{n}$. Masing-masing akar bernilai real atau mungkin bernilai kompleks yang memenuhi $f\left(r_{i}\right)=0$ untuk $i=1,2, \ldots n$. Dengan kata lain berlaku:

$$
f(r)=\left(r-r_{1}\right)\left(r-r_{2}\right),\left(r-r_{n}\right)
$$

Nilai eigen dari matriks A merupakan akar-akar dari polinomial $f(r)$.

Uji kestabilan Hurwitz untuk titik keseimbangan $O=(0,0, \cdots 0)$ pada sistem $(2.15)$ tidak melibatkan perhitungan niai eigen dari matriks A. Uji kestabilan Hurwitz menguji deteminan dari matriks $H_{n}$ yang disebut dengan matriks Hurwitz. Entri-entri matriks Hurwitz nilainya hanya memuat $0,1, p_{0}, p_{1}, p_{2}, \cdots p_{n-1}$. Maka matriks Hurwitz diberikan berikut:

$$
\begin{aligned}
& H_{1}=\left(p_{n-1}\right) \\
& H_{2}=\left(\begin{array}{cc}
p_{n-1} & p_{n-3} \\
1 & p_{n-2}
\end{array}\right) \\
& H_{3}=\left(\begin{array}{ccc}
p_{n-1} & p_{n-3} & p_{n-5} \\
1 & p_{n-2} & p_{n-4} \\
0 & p_{n-1} & p_{n-3}
\end{array}\right) \\
& H_{4}=\left(\begin{array}{cccc}
p_{n-1} & p_{n-3} & p_{n-5} & p_{n-7} \\
1 & p_{n-2} & p_{n-4} & p_{n-6} \\
0 & p_{n-1} & p_{n-3} & p_{n-5} \\
0 & 1 & p_{n-2} & p_{n-4}
\end{array}\right)
\end{aligned}
$$

Sampai matriks $H_{n}$. Dimana nilai $p_{j}$ didefinisikan bernilai nol jika $j$ bernilai negatif.

Teorema 2.3 Uji kestabilan Hurwitz (Jeffries, 1989). Misalkan setiap dinamik (2.15) mempunyai trajektori konstan nol. setiap matriks Hurwitz mempunyai determinan dengan nilai positif jika dan hanya jika setiap bagian real dari nilai eigen matriks $\mathbf{A}$ bernilai negatif dan nol merupakan suatu trajektori atraktor yaitu keseimbangan 0 stabil asimptotik.

Untuk nilai $n$ yang kecil, uji kestabilan Hurwitz menyatakan bahwa masing-masing matriks Hurwitz mempunyai determinan dengan nilai positif jika dan hanya jika untuk,

$$
\begin{aligned}
& n=1, p_{0}>0 \\
& n=2, p_{0}, p_{1}>0 \\
& n=3, p_{0}, p_{1}, p_{2}>0, p_{1} p_{2}-p_{0}>0 \\
& n=4, p_{0}, p_{1}, p_{2}, p_{3}>0, p_{3} p_{1} p_{2}-p_{1}^{2}-p_{0} p_{3}^{2}>0 .
\end{aligned}
$$

Dengan demikian, kestabilan titik keseimbangan nol dapat diketahui dengan memperhatikan nilai-nilai koefisien dari persamaan karateristik matriks A.

\section{BAHAN DAN METODE}


Secara umum kerangka penelitian ini dimulai dengan konstruksi model, tahapan penyelesaian yang mencakup penentuan titik ekuilibrium, melinearisasi model, analisis kestabilan titik ekuilibrium, kemudian melakukan simulasi numerik. Adapun variabel penelitian adalah menganalisis kestabilan model mangsa-pemangsa dengan fungsi respon tipe Holling III dan terjadi pemanenan pada populasi mangsa-pemangsa. Software komputasi yang digunakan pada penelitian ini adalah dengan menggunakan Maple.

\section{HASIL PENELITIAN}

Penelitian ini menunjukkan bahwa model mangsa-pemangsa dengan fungsi respon tipe Holling III memiliki dua titik ekuilibrium yang salah satunya merupakan titik interior yang stabil asimptotik berdasarkan uji kestabilan Hurwitz dan pemanenan pada populasi mangsapemangsa yang memberikan keuntungan maksimal. Model populasi mangsa-pemangsa dengan fungsi respon yang mengikuti tipe Holling III diberikan pada Persamaan (1) berikut:

$$
\begin{aligned}
& \frac{d x}{d t}=r x\left(1-\frac{r x^{2}}{K}\right)-\frac{m_{1} y x^{2}}{a_{1}+x^{2}} \\
& \frac{d y}{d t}=\frac{m_{1} y x^{2}}{a_{1}+x^{2}}-\beta y
\end{aligned}
$$

Suatu asumsi bahwa kedua populasi mangsa-pemangsa tersebut merupakan populasi yang sangat bermanfaat bagi kehidupan manusia, maka kedua populasi tersebut selanjutnya dieksploitasi dengan usaha pemanenan pada masing-masing ukuran populasi. Dengan pertimbangan tersebut model (3.1) maka dikembangkan menjadi,

$$
\begin{aligned}
& \frac{d x}{d t}=r x\left(1-\frac{r x}{K}\right)-\frac{m_{1} y x^{2}}{a_{1}+x^{2}}-q_{1} E_{1} x \\
& \frac{d y}{d t}=\frac{m_{1} y x^{2}}{a_{1}+x^{2}}-\beta y-q_{2} E_{2} x
\end{aligned}
$$

Dimana,

\begin{tabular}{|l|l|l|}
\hline No & Simbol & Keterangan \\
\hline 1 & $x, y$ & Ukuran populasi predator-prey \\
\hline 2 & $r$ & Laju pertumbuhan intrinsik \\
\hline 3 & $K$ & Daya dukung lingkungan (Carrying capacity) \\
\hline 4 & $E_{1}, E_{2}$ & Usaha pemanenan pada populasi predator-prey \\
\hline 5 & $m_{1}$ & Laju kelahiran predator \\
\hline 6 & $a_{1}$ & Konstanta kejenuhan predator \\
\hline 7 & $\beta$ & Laju kematian predator \\
\hline 8 & $q_{1}$ dan $q_{2}$ & Koefisien ketertangkapan \\
\hline
\end{tabular}

Dengan memisalkan $r_{1}=r-q_{1} E_{1}$ dan $r_{2}=\beta+q_{2} E_{2}$, maka model (3.2) menjadi

$$
\begin{aligned}
& \frac{d x}{d t}=r_{1} x-\frac{r x^{2}}{K}-\frac{m_{1} y x^{2}}{a_{1}+x^{2}} \\
& \frac{d y}{d t}=\frac{m_{1} y x^{2}}{a_{1}+x^{2}}-r_{2} y
\end{aligned}
$$

Berdasarkan model (3.3) diperoleh dua titik ekuilibrium yang non negatif, yaitu $T E_{l}(x, y)=(0,0)$ dan $T E_{2}(x, y)=\left(n_{1}, \frac{a_{1}\left(r_{1} K-r\right)}{\left(m_{1}-r_{2}\right) n_{1} K}\right)$ dimana, $n_{1}$ merupakan akar-akar dari persamaan $\left(m_{1}-r_{2}\right) Z^{2}-r_{2} a_{1}$. Titik $T E_{2}(x, y)$ merupakan suatu titik yang terjadi pada oktan pertama (titik interior) jika $n_{1}>0, a_{1}+n_{1}^{2}>0$ dan $a_{2}+n_{1}^{2}>0$ yaitu keadaan 
dimana kedua komponen titik tersebut bernilai positif. Oleh karena itu, analisis kestabilan hanya dilakukan pada titik $T E_{2}(x, y)$.

Titik keseimbangan $T E_{2}(x, y)$ model persamaan (1) diperoleh dengan menyelesaikan $\frac{d x}{d t}=0$, dan $\frac{d y}{d t}=0$ dengan melinearisasi model (4) dengan menggunakan matriks Jacobi.

$$
A=\left(\begin{array}{ll}
\frac{\partial f_{1}}{\partial x} & \frac{\partial f_{1}}{\partial y} \\
\frac{\partial f_{2}}{\partial x} & \frac{\partial f_{2}}{\partial y}
\end{array}\right)
$$

Untuk mencari nilai eigen matriks A yang berukuran $3 \times 3$, maka dapat digunakan persamaan $\operatorname{det}(\mathbf{A}-\lambda \mathbf{I})=0$ yang biasa disebut persamaan kateristik dari $\mathbf{A}$, yaitu $f(\lambda)=\lambda^{2}+a_{1} \lambda+a_{0}$ atau $f(\lambda)=\lambda^{2}+\left(\frac{r_{1} K-r}{K}-r_{2}\right) \lambda+\left(\frac{r_{1} r_{2} K-r}{K}\right)$. Menurut kriteria kestabilan Routh-Hurwitz titik $T E_{2}(x, y)$ stabil asimptotik jika dan hanya jika $a_{1}, a_{0}>0$ (Toaha, 2013). Dari metode linearisasi dan uji kestabilan Hurwitz, diperoleh titik $T E_{2}(x, y)$ stabil asimptotik sebagaimana ditunjukan pada Gambar 1 dan Gambar 2 berikut.

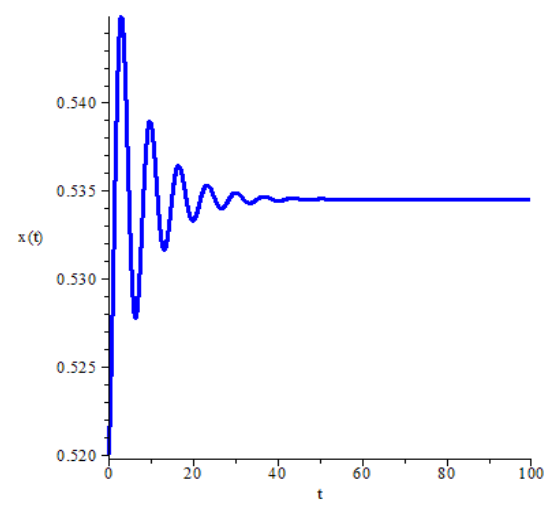

Gambar 1 Perilaku kurva solusi populasi mangsa

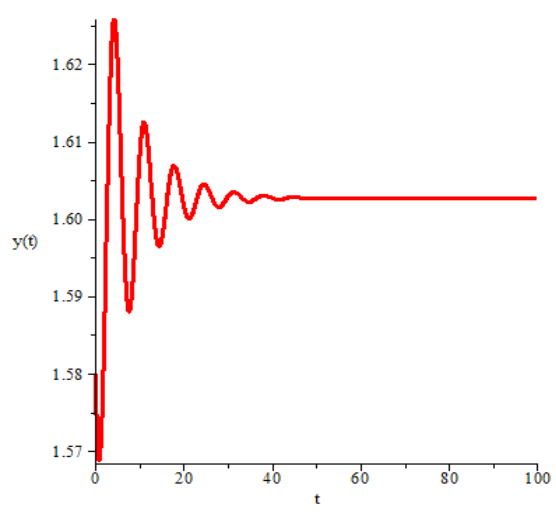

Gambar 2 Perilaku kurva solusi populasi pemangsa

Karena pada posisi titik keseimbangan $T E_{2}(x, y)$ pada persamaan (3.2) terjadi usaha pemanenan yang dikenakan pada populasi mangsa dengan asumsi bahwa $r-q_{1} E_{1}>0$ dan $\beta+q_{2} E_{2}>0$, serta dengan memisalkan $r_{1}=r-q_{1} E_{1}$ dan $r_{2}=\beta+q_{2} E_{2}$, maka $T E_{2}(x, y)$ menjadi $T E_{2}^{*}\left(x^{*}, y^{*}\right)=\left(n_{1}\left(r-q_{1} E_{1}\right), \frac{a_{1}\left(r_{1} K-r\right)\left(\beta+q_{2} E_{2}\right)}{\left(m_{1}-r_{2}\right) n_{1} K}\right)$.

Titik keseimbangan $E_{2}^{*}\left(x^{*}, y^{*}\right)$ yang stabil asimptotik dihubungkan dengan persoalan penerimaan total (TR), biaya total (TC) dan keuntungan maksimal $(\pi)$. Untuk keperluan analisis unit harga untuk stok populasi $\mathrm{x}$ dan populasi $y$ dinyatakan sebagai $p_{l}$ dan $p_{2}$. Biaya total diasumsikan proporsional hasil tangkapan dengan usaha pemanenan $E_{1}$ dan $E_{2}$ dengan koefisien $c_{1}$ dan $c_{2}$. Menurut Toaha (2014) fungsi penerimaan total (TR) dinyatakan sebagai berikut

$$
\begin{aligned}
T R & =T R(x)+T R(y) \\
& =p_{1} E_{1} x^{*}+p_{2} E_{2} y^{*}
\end{aligned}
$$

Selanjutnya, substitusi nilai $x^{*}$ dan $y^{*}$ ke dalam persamaan (3.4) sehingga diperoleh, 


$$
\begin{aligned}
T R & =p_{1} E_{1}\left(n_{1}\left(r-q_{1} E_{1}\right)\right)+p_{2} E_{2}\left(\frac{a_{1}\left(r_{1} K-r\right)\left(\beta+q_{2} E_{2}\right)}{\left(m_{1}-r_{2}\right) n_{1} K}\right) \\
& =p_{1} E_{1}\left(n_{1} r-n_{1} q_{1} E_{1}\right)+p_{2} E_{2}\left(\frac{a_{1} r_{1} \beta K+a_{1} r_{1} K q_{2} E_{2}-a_{1} \beta r-a_{1} r q_{2} E_{2}}{\left(m_{1}-r_{2}\right) n_{1} K}\right) \\
& =p_{1} E_{1}\left(n_{1} r-n_{1} q_{1} E_{1}\right)+p_{2} E_{2}\left(\frac{a_{1} r_{1} \beta K+a_{1} r_{1} K q_{2} E_{2}-a_{1} \beta r-a_{1} r q_{2} E_{2}}{\left(m_{1}-r_{2}\right) n_{1} K}\right) \\
& =p_{1} E_{1} n_{1} r-p_{1} n_{1} n_{1} q_{1} E_{1}^{2}+\frac{p_{2} a_{1} r_{1} \beta K E_{2}+p_{2} a_{1} r_{1} K q_{2} E_{2}^{2}-p_{2} a_{1} \beta r E_{2}-p_{2} a_{1} r q_{2} E_{2}^{2}}{\left(m_{1}-r_{2}\right) n_{1} K} \\
& =p_{1} E_{1} n_{1} r-p_{1} n_{1} n_{1} q_{1} E_{1}^{2}+\frac{p_{2} a_{1} r_{1} \beta K E_{2}-p_{2} a_{1} \beta r E_{2}+p_{2} a_{1} r_{1} K q_{2} E_{2}^{2}-p_{2} a_{1} r q_{2} E_{2}^{2}}{\left(m_{1}-r_{2}\right) n_{1} K} \\
T R & =p_{1} E_{1} n_{1} r-p_{1} n_{1} n_{1} q_{1} E_{1}^{2}+\frac{p_{2} \beta a_{1}\left(r_{1} K-r\right) E_{2}}{\left(m_{1}-r_{2}\right) n_{1} K}+\frac{p_{2} q_{2} a_{1}\left(r_{1} K-r\right) E_{2}^{2}}{\left(m_{1}-r_{2}\right) n_{1} K}
\end{aligned}
$$

Menurut Toaha (2014) fungsi biaya total (TC) dinyatakan sebagai berikut

$$
\mathrm{TC}=c_{1} E_{1}+c_{2} E_{2}
$$

Dengan mensubstitusikan nilai $T R$ pada Persamaan (3.5) dan nilai $T C$ pada Persamaan (3.6) sehingga akan diperoleh,

$$
\begin{aligned}
\pi & =\left(p_{1} E_{1} n_{1} r-p_{1} n_{1} n_{1} q_{1} E_{1}^{2}+\frac{p_{2} \beta a_{1}\left(r_{1} K-r\right) E_{2}}{\left(m_{1}-r_{2}\right) n_{1} K}+\frac{p_{2} q_{2} a_{1}\left(r_{1} K-r\right) E_{2}^{2}}{\left(m_{1}-r_{2}\right) n_{1} K}\right)-\left(c_{1} E_{1}+c_{2} E_{2}\right) \\
& =\left(p_{1} n_{1} r_{1}-c_{1}\right) E_{1}-p_{1} q_{1} n_{1} E_{1}^{2}+\frac{p_{2} \beta a_{1}\left(r_{1} K-r\right)-n_{1} K c_{2}\left(m_{1}-r_{2}\right)}{\left(m_{1}-r_{2}\right) n_{1} K} E_{2}+\frac{p_{2} q_{2} a_{1}\left(r_{1} K-r\right)}{\left(m_{1}-r_{2}\right) n_{1} K} E_{2}^{2}
\end{aligned}
$$

Karena titik keseimbangan $T E_{2}^{*}\left(x^{*}, y^{*}\right)$ bergantung pada usaha pemanenan yang dilakukan maka fungsi keuntungan bergantung kepada usaha pemanenan. Untuk menentukan nilai usaha pemanenan yang memberikan keuntungan maksimal, maka perlu ditentukan titik kritis usaha pemanenan. Berdasarkan Persamaan (3.7) maka diperoleh turunan pertama yaitu

$$
\begin{aligned}
& \frac{\partial \pi}{\partial E_{1}}=\left(p_{1} n_{1} r_{1}-c_{1}\right) E_{1}-p_{1} q_{1} n_{1} E_{1}^{2} \\
& \frac{\partial \pi}{\partial E_{2}}=\frac{p_{2} \beta a_{1}\left(r_{1} K-r\right)-n_{1} K c_{2}\left(m_{1}-r_{2}\right)}{\left(m_{1}-r_{2}\right) n_{1} K} E_{2}+\frac{p_{2} q_{2} a_{1}\left(r_{1} K-r\right)}{\left(m_{1}-r_{2}\right) n_{1} K} E_{2}^{2}
\end{aligned}
$$

Titik kritis dari persamaan (3.7) diperoleh dengan mengambil persamaan (3.8) yang sama dengan nol. Dengan demikian diperoleh titik kritis

a. Jika $\frac{\partial \pi}{\partial E_{1}}=0$, diperoleh $E_{1}=\frac{r_{1}-c_{1}}{2 q_{1}}$

b. Jika $\frac{\partial \pi}{\partial E_{2}}=0$, diperoleh $E_{2}=\frac{p_{2} a_{1} \beta\left(r_{1} K-r\right)-n_{1} K c_{2}\left(m_{1}-r_{2}\right)}{2 p_{2} q_{2} a_{1}\left(r_{1} K-r\right)}$

Nilai-nilai usaha pemanenan $E_{1}$ dan $E_{2}$ memberikan titik keseimbangan $T E_{2}^{*}\left(x^{*}, y^{*}\right)$ tetap berada pada keadaan yang stabil asimptotik serta memberikan keuntungan maksimal dari hasil eksploitasi ketiga populasi tersebut. Fungsi keuntungan dari ketiga populasi tersebut yang bergantung pada $E_{1}$ dan $E_{2}$ dimana keuntungan maksimal terjadi pada puncak dari permukaan fungsi keuntungan.

\section{SIMULASI NUMERIK}

Simulasi numerik dilakukan dengan memisalkan $K=1000, r_{1}=1,5, r=0.8, r_{2}=0.5, a_{1}=$ $0,4, m_{1}=1,2, p_{1}=0,1, p_{2}=0,3, c_{1}=0,1, c_{2}=0.2, q_{1}=0,4, q_{2}=0.4, n_{1}=1,2, b=0,5$ serta pemanenan optimal $E_{1}=1.667, E_{2}=1.084$, sehingga diperoleh titik keseimbangan $(x=$ $1,184104369 ; y=0.1678999787)$ dan juga memberikan $\pi_{\max }=162.68$. Semakin 
banyak usaha pemanenan yang dilakukan maka semakin banyak keuntungan yang didapatkan. Namun, jika menginginkan populasi mangsa pemangsa tetap lestari dan terjaga (tidak punah), maka usaha pemanenan dilakukan berdasarkan prosedur dan aturan yang berlaku, yaitu dengan mempertimbangkan kelahiran populasi mangsa pemangsa dan waku pelaksanaan pemanenan misalkan dilakukan setiap sekali seminggu.

Dengan menggunakan metode linearisasi diperoleh persamaan karakteristik $f(\lambda)=\lambda^{2}+$ $0.07266918928 \lambda+0.05486989492$. Dari persamaan karakteristik diperoleh $p_{0}=$ 0.05486989492 dan $p_{l}=0.07266918928$.. Karena $p_{0}, p_{1}>0$ maka menurut uji kestabilan Hurwitz, titik $T E_{5}^{*}\left(x^{*}, y^{*}, z^{*}\right)$ stabil asimptotik. Gambar 3 dan 4 berikut memperlihatkan kestabilan perilaku kurva solusi masing-masing populasi terhadap waktu (tahun) di sekitar titik ekuilibrium dengan nilai awal $\mathrm{x}(0)=1.19$ dan $\mathrm{y}(0)=0.17$.

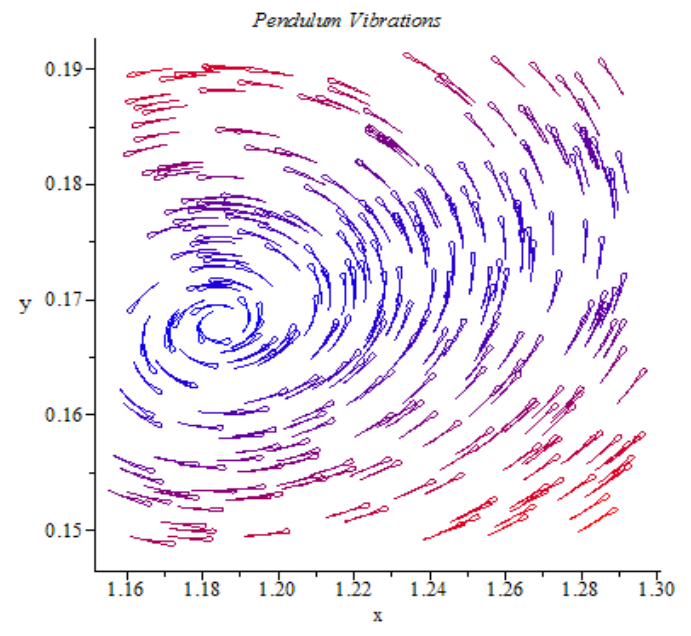

Gambar 1. Perilaku kurva solusi populasi mangsa pemangsa

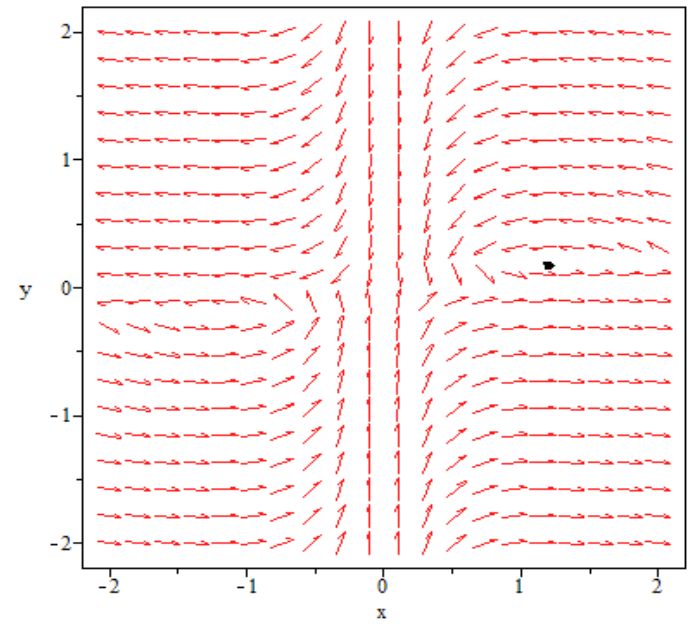

Gambar 2. Perilaku kurva solusi populasi mangsa pemangsa

\section{KESIMPULAN DAN SARAN}

Model mangsa-pemangsa dengan fungsi respon tipe Holling III dan pemanenan pada kedua populasi tersebut menunjukkan bahwa diperoleh titik interior $T E_{2}^{*}\left(x^{*}, y^{*}\right)$ yang stabil asimptotik menurut uji kestabilan Hurwitz dan diperoleh keuntungan maksimal dari usaha ekploitasi atau pemanenan populasi kedua pemangsa. Populasi mangsa pemangsa dapat tetap lestari (bertahan hidup) meskipun dieksploitasi dengan usaha pemanenan dan juga memberikan keuntungan maksimal yaitu sebesar $\pi_{\max }=162.68$ dimana didapatkan keuntungan maksimal terjadi pada puncak (titik kritis) dari permukaan fungsi keuntungan. Untuk penelitian selanjutnya, dapat menambahkan berbagai pertimbangan asumsi lainnya misalkan dengan asumsi menambahkan pengaruh waktu tunda untuk melihat perubahan dinamika populasi organisme.

\section{DAFTAR PUSTAKA}

Agarwal, M. and R. Pathak. (2012). Persistence and optimal harvesting of prey-predator model with Holling Type III functional response. International Journal of Engineering, Science and Technology Vol. 4, No. 3 : 78-96

Anton, Howard. 1995. Aljabar linear elementer. Edisi kelima. Terjemahan Pantur Silaban dan I Nyoman susila. Jakarta: Erlangga 
Brauer, Fred and Carlos Castillo-Chavez. 2012. Mathematical Models in Population Biology and Epidemiology. Second Edition. New York Dordrecht Heidelberg London: Springer.

Jeffries, C. (1989). Mathematical modeling in ecology. Boston: Birkhauser.

Jiang, Q. and J. Wang. (2013). Qualitative analysis of a harvested predator-prey system with Holling type III functional response. Advances in difference equations a Springer Open Journal: $249-258$

Kar, T.K., 2003. Selective Harvesting in a Prey Predator Fishery With Time Delay. Mathematical And Computer Modelling. 38:449-458.

Liu, X. and Y. Xing. (2012). Qualitative Analysis for a Predator Prey System with Holling Type III Functional Response and Prey Refuge. Hindawi Publishing Corporation Discrete Dynamics in Nature and Society Volume 2012, Article ID 678957.

Srinivasu, P.D., Ismail, S., and Naidu, C.R. (2001). Global dynamics and controllability of a harvested prey-predator system. Journal Biological System, 9(1): 67-79

Tarumingkeng, Rudy C. 1994. Dinamika Populasi; Kajian Ekologi Kuantitatif. Jakarta: Pustaka Sinar Harapan dan UKRIDA

Toaha, Syamsuddin. (2013). Pemodelan Matematika Dalam Dinamika Populasi. Makassar: Dua Satu Press.

Toaha, Syamsuddin, et al. "Stability Analysis and Maximum Profit of Predator-Prey Population Model with Time Delay and Constant Effort of Harvesting." Malaysian J. Math. Sci 2.2 (2008): 147-159.

Tu, P.N.V. 1994. Dynamical System; An Introduction with Application in Economics and Biology. Heidelberg Germany: Springer-Verlag.

Wang, J. and Liqin Pan. (2012). Qualitative analysis of a harvested predator-prey system with Holling-type III functional response incorporating a prey refuge. Advances in difference equations Springer Open Journal: 96-112

Zhang, X., Xu, R., dan Gan, Q. (2011). Periodic Solution in a Delayed Predator Prey Model with Holling Type III Functional Response and Harvesting Term. World Journal of Modelling and Simulation. Vol. 7 No. 1: 70-80

Zhao, J., Zhao, M. and Yu, H. (2013). Effect of Prey Refuge on the Spatiotemporal Dynamics of a Modified Leslie-Gower Predator-Prey System with Holling Type III Schemes. Journal entropy, 15: 2431-2447 